\title{
Trettio års litteraturstöd till barn- och ungdomslitteratur - en tillbakablick
}

Statligt stöd till utgivning av litteratur är sedan 1975 en del av den svenska kulturpolitiken. I följande artikel presenteras litteraturstödet till barn- och ungdomslitteratur, dess tillkomst, utformning, utveckling och betydelse. Dessutom studeras de kriterier som använts $i$ diskussionerna om vilka böcker som skall ges stöd och hur motiveringarna för avslag har dokumenterats. Artikelförfattare är Alvar Wallinder, som tidigare utgivit Vem bestämmer? Svensk barnlitteraturutgivning - människor, miljöer och värderingar.

Statligt stöd till utgivning av litteratur infördes den 1 juli 1975. Redan på 1960-talet aktualiserades behovet av stöd. 1968 års litteraturutredning (L68) ställde frågan om litteraturens ställning i det svenska samhället $\mathrm{i}$ en ny belysning. Utredningen, vars ordförande blev redaktör Kaj Björk, skulle enligt regeringens direktiv pröva vilka stödåtgärder som kan vara lämpliga för utgivning av kulturellt värdefull litteratur. I direktiven konstateras att det inte kan vara fråga om att avlasta förlagen deras normala utgifter. Den norska inköpsordningen från 1965 med ett statligt inköp av 1000 exemplar av varje norsk skönlitterär bok var en av de omständigheter som påverkade beslutet att utreda en svensk motsvarighet. En viss minskning av bokutgivningen av skönlitteratur under 1960-talet och en höjning av bokpriserna, en följd av att de fasta bokpriserna upphävts, under samma tid hörde också till de förhållanden som medverkade till regeringens beslut att utreda frågan om former för litteraturstöd. Den s.k. förlagskrisen 1970-1971 hade också inverkan på litteraturutredningens arbete.

\section{För och emot litteraturstöd}

I den allmänna debatten kom litteraturpolitiken, en del av kulturpolitiken, att ses som en av välfärdspolitikens yttringar. Argument mot ett statligt kulturstöd var risken för att konstnärernas oberoende gentemot staten skulle minska. Detta gäller givetvis även det stöd som tilldelas litteraturen. Författare som får ekonomiskt stöd av staten får svårare att kritisera de rådande allmänna politiska värderingarna. Läsarnas valfrihet skulle också kunna minska om det finns en statlig instans som gör prioriteringar i utbudet av litteratur. Å andra sidan kan författarna bli alltför beroende av efterfrågan på marknaden om ett statligt stöd ej utgår. Valfriheten ökar för läsarna, om utbudet ej är beroende av förlagens ekonomiska bedömningar.

\section{Yttrandefrihet och kulturell förnyelse}

L68:s arbete resulterade i fyra delrapporter: Läs- och bokvanor i fem svenska samhällen (SOU 1972:20), Försök med bibliotek (SOU 1972:61), En bok om böcker (SOU 1972:80) samt Littera- 
turen $i$ skolan (SOU 1973:1.) I huvudbetänkandet Boken (SOU 1974:5) frågar utredningen om boken är på väg att konkurreras ut av modernare media. De ekonomiska betingelserna för utgivning hotar mångfald och mångsidighet. Vidare betonas att det för samhällsutvecklingen är viktigt att poängtera litteraturens betydelse. Utredningen konstaterar att "boken har spelat en stor roll i den fortgående andliga och politiska omvandlingsprocessen" (s. 83).

Utredningens slutsats blir att "det är ett självklart kulturpolitiskt mål att främja tillblivelse och tillägnan av god litteratur" (s. 85). Yttrandefrihet och kulturell förnyelse är viktiga motiv för ett litteraturstöd. En allsidig utgivning kan leda till att nya grupper vinns för läsning av god litteratur. För barnoch ungdomslitteraturen konstaterar utredningen att "det finns ett starkt behov av att garantera en god och jämn utgivning och spridning av kvalificerad barn- och ungdomslitteratur, både i original och i översättning. Detta måste ske om man vill nå målet att skapa goda läsvanor och en kritisk inställning till skräplitteraturen" (s. 316).

Slutförslaget blir att ett generellt stöd skall utgå till ny svensk skönlitteratur för vuxna med bl.a. restriktionen att texten till övervägande del skall publiceras för första gången och att boken via Bibliotekstjänsts sambindning inköpas i minst 40 exemplar till 24 länsbibliotek. Förlagets motprestation skall vara att ställa ett visst antal exemplar av den stödberättigade boken till statens förfogande för distribution till bibliotek och bokhandel. Ett selektivt stöd skall införas för övrig litteratur, bl.a. barn- och ungdomslitteratur. Det senare skall utformas som ett stöd antingen i för- eller i efterhand och föregås av beslut $i$ en nämnd som bedömer böckerna med särskild hänsyn till kvalitetsaspekten. För barn- och ungdomslitteraturen motive- ras detta med att denna haft en rimlig lönsamhet under det senaste decenniet.

Debatten blev intensiv efter publiceringen av huvudbetänkandet. Bokförläggareföreningen såg en momsbefrielse som ett alternativ till utgivningsstöd. Sveriges författarförbund förordade en selektiv stödordning, dock med "vida ramar". Sveriges Allmänna Biblioteksförening ville öka det generella stödet och framhöll att barn- och ungdomslitteraturen bör stödjas i väsentligt högre omfattning än vad som framgick av L68:s förslag, bl.a. genom läsfrämjande åtgärder.

\section{Ideologiska bedömningar}

I regeringens proposition Den statliga kulturpolitiken 2 (Prop. 1975:20) skedde förändringar i jämförelse med utredningens förslag. Utbildningsminister Bertil Zachrisson hävdade att stödet bör inriktas på de litteraturkategorier där utgivningen är begränsad, bl.a. barn- och ungdomslitteratur. Ett selektivt efterhandsstöd skulle utgå, framför allt till debutböcker, och beloppet skulle uppgå till en halv miljon, jämfört med Litteraturutredningens förslag 5,4 miljoner per år.

Debatten blev synnerligen livlig inför utskottsarbetet i riksdagen. Sveriges författarförbund föreslog ett selektivt efterhandsstöd till en kostnad av 3,3 miljoner. Förlagens motprestation skulle vara ett maximerat förlagsnettopris (f-pris, det pris förlaget säljer boken för exklusive moms). Det var av vikt att utgivningen av kvalitetsböcker kunde ökas och att bokpriserna hölls nere. Vid riksdagsbehandlingen av ärendet anslöt sig de borgerliga partierna i huvudsak till L 68:s förslag. Vänsterpartiet kommunisterna (Vpk) tog över författarförbundets förslag och i den "jämviktsriksdag" som fungerade 19731976 följde riksdagen med en rösts övervikt socialdemokraternas och Vpk:s reservation $\mathrm{i}$ kulturutskottet. Beslutet blev alltså ett selek- 
tivt litteraturstöd med såväl produktionsstöd som efterhandstöd. Stödet skulle utgå i form av arkersättning beräknat på bokens omfång, där sexton sidor motsvarar ett normalark.

Nära trettio år senare, i juni 2004, kommenterar Bertil Zachrisson i ett brev till mig sin syn på tankarna bakom propositionen:

De ideologiska bedömningarna var helt avgörande. Litteratur är en hörnsten $i$ samhällets kulturella ansvar. Den kritik vi mötte från föräldrar, skolor och andra intressegrupper hade nästan alltid ideologiska förtecken. God tillgång till prisbilliga böcker och läsfrämjande åtgärder återkom ständigt $i$ kritiken, och på ett djupare plan litteraturens betydelse för språkutveckling och för förståelse av samhällsutveckling och idédebatt. De litterära bedömningarna överläts åt fackfolk, men spelade en roll $i$ arbetet med att skapa alternativ till den sk kiosklitteraturen.

\section{Förordningar och mål}

Den första förordningen om statligt litteraturstöd kom 1975 (SFS 1975:493). I den första paragrafen anges målet: "För att främja mångsidighet och kvalitet $\mathrm{i}$ bokutgivning kan stöd enligt denna förordning utgå till svenskt förlag här i landet." I förordningen fastställs också att Statens Kulturråd skall pröva frågan om stöd. För barn- och ungdomslitteratur kan stöd utgå dels som produktionsstöd, dels som stödköp av 1000 exemplar per titel. Dessa skall fördelas till organisationer som arbetar med läsfrämjande verksamhet. Under tiden efter 1975 har den ursprungliga förordningen ändrats flera gånger. Den nu aktuella förordningen kom 1998 (SFS 1998:1469). Begreppen mångsidighet och kvalitet har varit oförändrade. I Kulturrådets skrift Allmän information om litteraturstödet 2004 har angivits följande syfte: "att främja kvalitet och mångsidighet i bokutgivningen så att läsarna garanteras ett brett urval av god litteratur". Här finns allt- så ett icke definierat begrepp "god". Hur begreppet tolkas framgår av de faktiska besluten gällande stöd men också av de definitioner gällande bedömningsgrunder som finns i samma dokument.

\section{Stödordningar}

Det finns anledning att här erinra om den debatt som fanns före stödets införande och som gällde hur ett övergripande statligt ansvar för kulturutbudet skulle kunna påverka konstnärerna/författarna och inom litteraturens värld de olika förlagen. Ändringarna i förordningarna har framför allt gällt indelningen i stödordningar, från början åtta, till f.n. tio, där den sista tidstypiskt gäller elektroniskt publicerad litteratur. Förfarandet med stödköp av barn-och ungdomslitteratur upphörde redan 1978. I förordningen 1998:1469 infördes en upplagespärr, vilken innebär att stödbeloppet reduceras med $50 \%$, om titeln trycks i en förstaupplaga av större omfattning. Kulturrådet fastställer varje år vilken upplagenivå som skall gälla för en sådan reducering. I januari 2004 fattade kulturrådets styrelse beslutet att ange upplagegränsen till 5000 exemplar. En lägre gräns skulle enligt styrelsen främst drabba barnböcker, som generellt trycks i stora upplagor.

För år 2004 är stödet i huvudsak ett efterhandsstöd till första utgåvan av en bok. Ansökan kan göras av förlag, verksamma i Sverige. Stödet avser med vissa undantag litteratur på svenska. För böcker skrivna på invandrarspråk och för nationella minoriteters litteratur finns särskilda stödformer. Stödbelopp och högsta tillåtna förlagsnettopris fastställs årligen. I detta sammanhang kan nämnas att i bokutredningens slutbetänkande Boken $i$ tiden (SOU 1997:141) gjordes uppskattningen att utgivningsstödet inte motsvarar mer än högst $1 \%$ av bokmarknadens totala omsättning (s. 159). 
Det är värt att notera att litteraturstödet inte strider mot EU:s konkurrensregler, då åtgärder på den svenska bokmarknaden endast obetydligt påverkar handeln över gränserna. Maastrichtfördraget artikel 128 (artikel 151 i det nu gällande fördraget), den s.k. kulturartikeln, innebär bl.a. att EU:s åtgärder inte skall medföra en harmonisering av medlemsstaternas åtgärder (Boken i tiden, SOU 1997:141, s. 193-201).

Den första utredningen om litteraturstöd fick flera efterföljare. Här kan nämnas Statligt litteraturstöd (Dsu 1977:14), Stöd till bokutgivning och bokförlag - en utvärdering ( Dsu 1981:5), Läs! Rapport från 1982 års bokutredning (Liber Förlag) samt Läs mera! (SOU 1984:30). Under 1970-talet tillkom Litteraturfrämjandets serie "En bok för alla" med statligt stöd och vidare infördes stöd till olika distributionsformer. Den senaste utredningen är den ovan nämnda Boken $i$ tiden (SOU 1997:141), ett betänkande från Utredningen om boken och kulturtidskriften. Resultatet blev propositionen Litteraturen och läsandet (Prop. 1997/98:86) med efterföljande riksdagsbeslut 1998 om bl.a. ett nytt statligt stöd för utgivning och distribution av böcker till folkbiblioteken samt ett nytt statligt stöd för läsfrämjande insatser. I propositionen hänvisas till utredningens redovisning av ett minskat bokläsande bland barn och ungdomar.

\section{Stöd till barn- och ungdomslitteratur}

En genomgång av Kulturrådets statistik och av de beslutshandlingar som finns arkiverade visar i stora drag hur stödet utvecklats under de gångna trettio åren. I denna uppsats koncentreras uppmärksamheten på stödet till barn- och ungdomslitteratur. Det bör observeras att under de båda första åren utgick produktionsstöd och medel till stödköp.

Antalet sökande förlag har varit tämligen konstant, mellan fyrtio och femtio. Vissa förlag har haft det största antalet ansökningar, mer än tjugo per år. Bonniers Juniorförlag, Bonnier Carlsen, Rabén \& Sjögren samt Opal hör till denna grupp. Under tidsperioden har tillkommit de förlag som utger översättningar till olika invandrarspråk.

\section{Stadig ökning av ansökningar}

Antalet ansökningar har sedan 1975 visat en viss ökning. Det första året inkom 342 ansökningar (till stödköp!), och under 1980talet, då ansökningarna gällde efterhandsstöd, var antalet oförändrat medan en ökning kom i mitten av 1990-talet och början av 2000-talet, då omkring 400 ansökningar inlämnades varje år. Under de båda första åren fick ca 30 \% av ansökningarna beslut om stöd. Antalet ökade till i genomsnitt 40 \% under 1980-talet, och siffran steg till omkring 50 \% först under 2000-talet. Det under åren varierande antalet beviljade stöd kan ha samband med böckernas språkliga och innehållsmässiga kvalitet men också relateras till att vissa år inkommer en större mängd böcker av allmänt erkända författare. Variationen i antalet beviljade stöd kan också ha sin grund i skiftande värderingsnormer i de olika arbetsgrupperna. Frånvaron av skriftlig dokumentation gällande värderingsgrunder för de olika besluten under de aktuella åren omöjliggör en trovärdig slutsats.

\section{Litteraturstödets utveckling}

Vilka medel har arbetsgrupperna haft till sitt förfogande? Det totala beloppet beslutas av riksdagen. Fördelningen mellan de olika kategorierna fastställs av kulturrådets styrelse och baseras på föregående års utfall, antal ansökningar och beviljade stöd. Av de medel som kulturrådet disponerar har barn- och ungdomslitteraturen prioriterats under de senaste åren. 
Beviljat utgivningsstöd, delposten barn- och ungdomslitteratur

\begin{tabular}{lll} 
Årtal & $\begin{array}{l}\text { Löpande } \\
\text { penningvärde }\end{array}$ & $\begin{array}{l}\text { Fast } \\
\text { penningvärde }\end{array}$ \\
\hline $1975-1976$ & 1220000 & 1220000 \\
$1980-1981$ & 2326000 & 1259561 \\
$1985-1986$ & 2494000 & 944971 \\
$1990-1991$ & 3311910 & 885105 \\
1997 & 4381000 & 1033496 \\
1999 & 5445000 & 1280412 \\
2002 & 6659000 & 1481819 \\
2003 & 6423000 & 1402215
\end{tabular}

Det totala beloppet beviljade utgivningsstöd 1975/76 var $6439000 \mathrm{kr}$. I löpande penningvärde har det totala beloppet ökat till $38130000 \mathrm{kr}$ år 2003. I detta belopp ingår också stöd till distribution. Det har alltså skett en mycket stor ökning från begynnelseåret. Om man med hjälp av SCB:s konsumentprisindex förvandlar beloppet till fast penningvärde med 1975 som utgångspunkt blir bilden en annan. Det totala beloppet blir då $8324221 \mathrm{kr}$.

Det har skett en mycket stor ökning, såväl gällande det totala beloppet, omkring trettiotvå miljoner kronor, som beloppet för barnoch ungdomslitteratur, omkring fem miljoner kronor. Beträffande de exakta summorna bör noteras att under vissa år har utbetalningen och därmed bokföringen skett året efter besluten. Med den ovan gjorda omräkningen och med beaktande av att beloppens ändamål ej är helt jämförbara kan man dock konstatera att summan ej ökat nämnvärt sedan startåret. En annan jämförelse kan göras mellan det totala beloppet beviljade utgivningsstöd och den del som utgör stöd till barn- och ungdomslitteratur. Under tiden 1991-2002 har andelen till den sistnämnda kategorin ökat från ca 14 till ca 19 \%.

\section{Arbetsgruppernas verksamhetsformer}

Statens Kulturråd tillsatte vid verksamhetens början arbetsgrupper som skulle föreslå beslut om litteraturstöd. Detta gällde samtliga stödområden. Från och med 1987 fick arbetsgrupperna också mandat att själva fatta beslut, vilket de i praktiken redan från början hade gjort. Kulturrådets styrelse utser ordförande och ledamöter i grupperna. Under de första åren tillsattes ordförandeposten av LB-nämnden (Nämnden för litteratur och bibliotek), ett organ som upphörde 1987. Förslag till ledamöter lämnas av respektive handläggare. Sammansättningen av arbetsgruppen för barn- och ungdomslitteratur speglade från verksamhetens början - och speglar fortfarande - barnbokssamhällets olika intressenter: författare, barnlitteraturforskning, bibliotek och skola. Hänsyn tas vid beslut om ledamöter till kön, ålder och geografisk hemvist men framför allt har ledamöternas individuella kompetens beaktats. Sekreterare och handläggare var - och är fortfarande - en tjänsteman vid kulturrådet, som också fungerar som gruppens språkrör mot omvärlden. Frånsett de första 
sex åren - då i stort sett samma personer var ledamöter hela tiden - har gruppen successivt förnyats. Genomgående har ledamöterna utsetts för tvåårsperioder. Ordförandena hämtas huvudsakligen från skol- och biblioteksområdena. Ett rent politiskt mandat hade den andre ordföranden, läkaren Lars Weinehall, som företrädde centerpartiet $\mathrm{i}$ LB-nämnden.

\section{Motivering av avslag}

Under de första åren krävdes total enighet bland ledamöterna vid beslut om stöd. Praxis ändrades redan under 1980-talet, så att majoritetsbeslut blev gällande. Besluten protokollfördes, dock utan att motiveringar angavs i protokollen. Detta förfaringssätt har bestått under de trettio åren och har även ifrågasatts. Ulla Forsén, bibliotekarie och senare (1994-1997) ordförande i arbetsgruppen, slog 1986 larm om det statliga stödet. Under rubriken "Många? kring det statliga stödet för barn- och ungdomslitteratur" ( $A b$ rakadabra 1986:31) efterlyste hon en öppen diskussion om litteraturstödet. Hon konstaterar att hon på förfrågan hos kulturrådets tjänstemän inte fått kunskap om kvalitetskriterierna för beslut: "Några sådana kan man inte stå till tjänst med. Hade man haft sådana skulle det vara liktydigt med censur. Det är anslagssumman som sätter kvalitetsgränserna."

I en artikel av läraren och litteraturpedagogen Jan Nilsson, "Stöd eller inte stöd?" (Arbetet 10.7.1987) försvarar han, som varit ledamot i gruppen 1980-1987, förfaringssättet med följande motivering: "...om vi skulle skriva oss samman till oantastliga motiveringar för varje beslut skulle merparten av tiden gå åt till att fila på formuleringar i stället för att läsa, resonera och fatta beslut". Karin Monié, handläggare i arbetsgruppen 1978-1981, hävdar att det skulle vara alltför svårt att på ett juridiskt hållbart sätt motivera avslag (telefonintervju 200409-21). Jan Nilssons motiveringar framkom även vid min intervju 2004-10-05 med ledamöterna i den arbetsgrupp som har ansvaret 2004. En liknande inställning har förlagschefen Kerstin Aronsson, förlagschef vid Kabusa förlag. Hon hävdar "att det finns risk att det krävs så mycket arbetstid och energi vid skriftliga motiveringar av beslut om avslag att stödet äventyras" (telefonintervju 2004-09-30). Enligt Signe Westin, handläggare med samordnande funktioner fr.o.m. 2003, skulle avslagsbesluten, som ju är en offentlig handling, på ett olyckligt sätt utpeka en enskild författare om detaljerade motiveringar ingår i beslutsformuleringen (intervju 2004-10-05). Samma uppfattning har Birgitta Modigh, avdelningschef vid kulturrådet: "att ge individuellt utformade omdömen för avslag är olyckligt och negativt för författarna (=tredje part)" (brev 2004-10-12). De olika ansvarigas skäl för att ej utforma motiverade avslag grundas alltså dels på praktiska skäl, dels på hänsynstagande till den aktuella författarens reaktioner.

\section{Öppenhet - slutenhet}

Svårigheten att utforma individuella, väl avvägda motiveringar till den stora mängden bidragsbeslut framhävs också i en särskild PM Arbetsgrupper och referensgruppervid Kulturrådet, september 2003. I denna PM framhålls att många bidragssökande accepterar frånvaron av skriftliga motiveringar men att man ändå vill finna en modell som ger tillräcklig vägledning för den sökande som fått avslag. Enligt mina intervjuer med handläggare är det endast ett fåtal förlag som begär skriftliga motiveringar. Intervjuer med förläggare kan komplettera denna bild. Rod Bengtsson, förläggare vid Bonnier Carlsen Bokförlag och medlem i Svenska Förläggar- 
föreningens referensgrupp för litteraturstöd, anser att" det vore önskvärt med motiveringar för såväl positiva som negativa beslut". En konsekvens av detta skulle dock kunna bli att ett offentligt negativt beslut skulle försätta den enskilde författaren i ett utsatt läge. För närvarande är författarna föga intresserade av kulturrådets bedömning men skulle vid öppna beslut kunna kräva detaljerade motiveringar från kulturrådet (telefonintervju 2004-10-13).

Marianne Eriksson, förläggare vid Eriksson \& Lindgren Bokförlag, delar Rod Bengtssons uppfattning. "Det vore en stor fördel om motiveringarna anges till förlaget p.g.a. vikten av öppenhet i hanteringen." Hon jämför i detta sammanhang med de yttranden som görs av Bibliotekstjänsts lektörer (telefonintervju 2004-10-15). David Stansvik, förlagschef för Bokförlaget Nya Doxa och ordförande i intresseföreningen NOFF (Nordiska föreningen för mindre förlag) ser däremot ingen nackdel med att kulturrådet ej skriftligt motiverar sina beslut. "Tydliga motiveringar skulle kunna skapa en sorts anpasslighet hos förlagen när det gäller kommande utgivning." Det allmänna regelverket för olika stödkategoriers möjligheter till stöd är tillräckligt. Det är viktigt att vid bedömningen hänsyn tas endast till kvalitetskriterierna och ej till förlagens storlek (telefonintervju 2004-10-13). Företrädare för såväl ett stort som två mindre förlag kommer alltså fram till olika slutsatser när det gäller behovet av skriftliga motiveringar.

\section{Beslutsdokumentation}

Diskussionerna om behovet av beslutsdokumentation har dock lett till att fr.o.m. 2003 får förlag som fått avslag på sin stödbegäran ett beslutsmeddelande med generella, ej individuella, motiveringar varför stöd inte beviljas. Brevet är identiskt för samtliga stödom- råden. Där understryks att alla böcker läses och bedöms var för sig: "Det har alltså inte någon betydelse vilket förlag som ger ut boken, inte heller om boken är ekonomiskt lönsam eller ej. / .../ Grunden för bedömningen är alltid bokens kvalitet. Bedömningskriterierna kan skifta från kategori till kategori." Därefter följer en hänvisning till de centrala begreppen intensitet, originalitet och komplexitet: "Språket är en väsentlig del av bedömningen av all litteratur. För barn- och ungdomsböcker skall det vara anpassat till den tänkta målgruppen." I brevets avslutning hänvisas till förordningen (1998:1469) att beslutet inte kan överklagas. Här finns inte den upplysning som ges i kulturrådets PM Allmän information om litteraturstödet att beslut kan, om särskilda skäl föreligger, prövas på nytt. En sådan omprövning kan ske endast en gång per titel.

\section{Alternativa sätt att fördela litteraturstöd}

Våren 2003 fick förläggaren och författaren Björn Linnell kulturrådets uppdrag att försöka hitta alternativa sätt att fördela litteraturstöd, vilka skulle innebära mindre arbete för kulturrådet. Formerna för stödet skall vara tydliga och det skall finnas en " koppling mellan mål och resultat". I en PM 200304-24 lägger han fram olika förslag för att spara kostnader i samband med fördelningsarbetet. En viktig arbetsbesparande åtgärd är att förlagen själva sänder sina stödsökta böcker direkt till arbetsgrupperna. En avgörande förändring i gruppernas arbetssätt skulle vara följande: skriftliga motiveringar för besluten skall finnas tillgängliga för kulturrådets tjänstemän men även för utomstående. Detta skulle skapa "större genomskinlighet för motiven bakom besluten och även underlätta för arbetsgrupperna att motivera besluten vid förfrågan". Det skulle dock inte 
vara signerade recensioner av namngivna läsare från arbetsgrupperna.

Vid ett möte kring Linnells PM med ordförandena i de olika arbetsgrupperna 200305-27 hävdade kulturrådets generaldirektör Kristina Rennerstedt att "skriftliga omdömen vid avslag skulle ge transparens och därmed förtroende". I diskussionsprotokollet hänvisas också till det arbete med kriterier som redan diskuterats i arbetsgrupperna. Här nämns också att arbetsgruppen för barn- och ungdomslitteratur upprättat förhållandevis detaljerade förteckningar över kriterier (se nedan avsnittet "Nyckelord och värderingsgrunder"). Ett förslag är att ordföranden skall skriva ner nyckelord på arbetslistorna. I protokollet noteras dock att "ett kompakt motstånd" mötte förslaget om skriftliga motiveringar för varje titel, vilka skulle kunna fogas in i ett avslagsbrev. Ett sådant individuellt formulerat avslagbrev har inte kommit till stånd efter detta möte. Det generellt utformade brev, som citerats ovan i min redogörelse, används vid avslagsbesluten och det har varit möjligt för förlagsföreträdaren att av handläggaren få närmare besked, en möjlighet som dock ej utnyttjats i någon högre utsträckning.

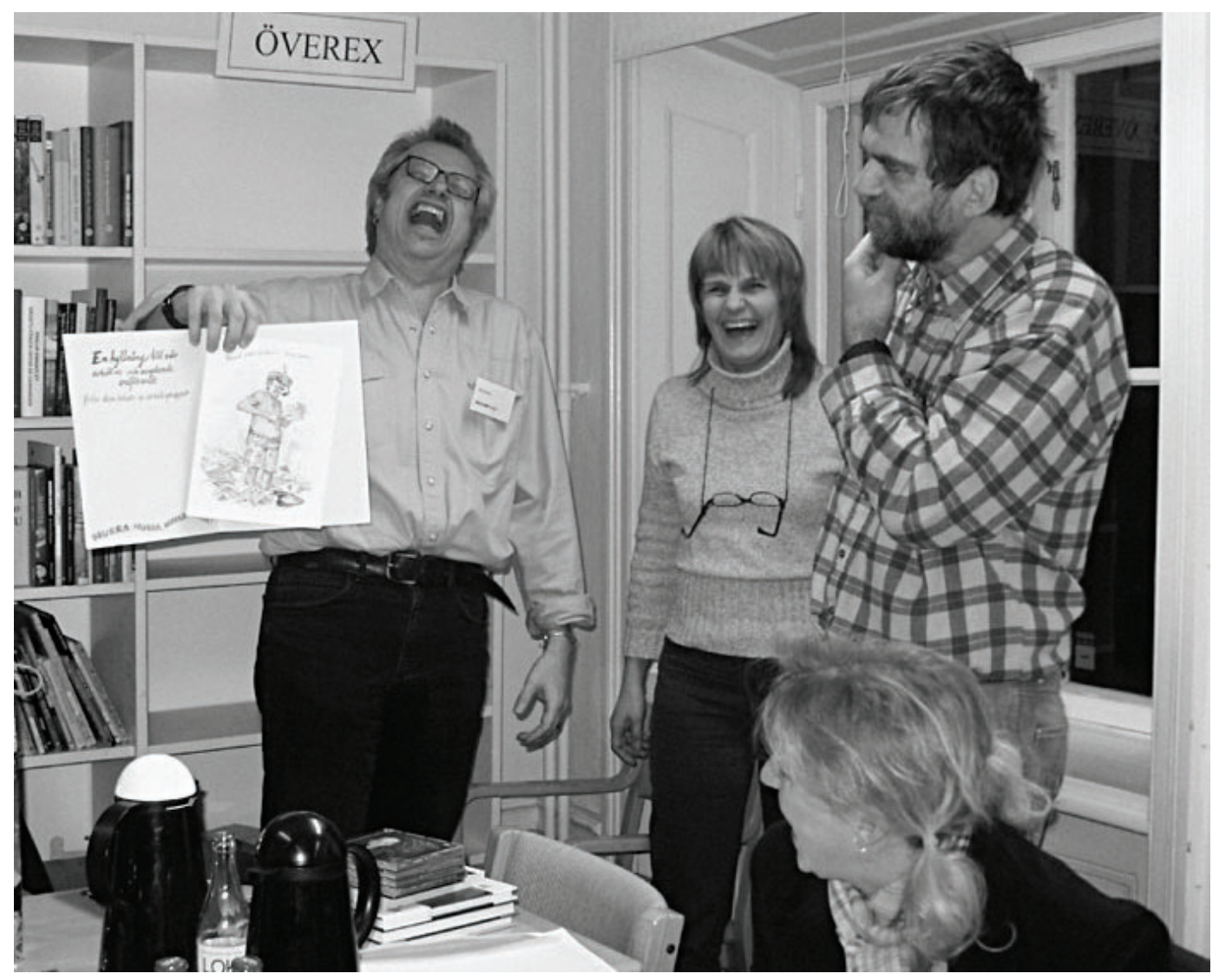

Avgående ordförande för arbetsgruppen Staffan Wennerlund får ett originalkort av illustratören Jens Ahlbom. Teckningen föreställer Staffan letande "pärlor i bokfloden" - just det som arbetsgruppen ägnar sig åt. Med på fotot är konstnären själv, Tua Stenström, Kulturrådet och sittande vid bordet Maria Rohlin. 2004. 


\section{Omarbetning av beslutsmeddelanden}

Frågan om beslutsmotiveringar har aktualiserats vid ett nytt möte med arbetsgruppernas ordförande 2004-09-07. Av protokollet framgår att kulturrådet håller på att omarbeta beslutsmeddelandena. Detta sker med hänvisning till förvaltningslagen, som säger att beslut skall innehålla anledningen till bifall eller avslag. Om ett förlag begär motivering, skall handläggaren ange vilka kriterier som gjort att "boken inte ansågs hålla måttet". I protokollet står följande: "Kulturrådet strävar efter rättssäkerhet, öppenhet och tydlighet gentemot såväl sökande som allmänhet." Att frågan anses viktig framgår också av ordförandenas uppfattning att $\mathrm{i}$ informationen om litteraturstöd skall anges de specifika bedömningsgrunder som tillämpas för varje kategori. Kristina Rennerstedt har genom avdelningschefen Birgitta Modigh uttalat följande i ett brev till mig: "Kulturrådet utvecklar ständigt formerna för beslut. Hittills har vi använt positiva generella motiveringar - men vi använder också negativa generella motiveringar 'uppfyller inte kraven på kvalitet...'" (brev 2004-10-28). Det är tydligt att den interna diskussionen inom kulturrådet fortsätter med spännvidden mellan förvaltningslagens krav på offentligt motiverade beslut och handläggarnas erfarenhetsgrundade syn på arbetstidskonsekvenserna för de olika beslutsgrupperna och på risken för de enskilda författarnas reaktioner vid detaljerade beslutsmotiveringar.

\section{Kontinuitet i bedömningssätten}

Arbetsgruppernas handläggare har haft en sammanhållande och därmed stark ställning i det inre arbetet. Även om de inte själva deltagit i diskussionerna inför besluten har de genom sin sakkunskap om stödförfaran- det medverkat till en viss kontinuitet i bedömningssättet. Gruppernas sammansättning har givetvis haft den största betydelsen för arbetet. Detta framkommer också i de informella samtal som jag haft med olika gruppmedlemmar.

Hur har handläggarna själva uppfattat gruppernas arbete och sin egen roll? Den första handläggaren, Helena Sandblad, fann att gruppen för barn- och ungdomslitteratur var den "mest levande" av de olika grupperna. Där fanns en tydlig vilja att skapa opinion för barnboken (telefonintervju 1995-1031). Den ovan omnämnda handläggaren Karin Monié, efterträdare till Helena Sandblad, sade vid min telefonintervju med henne 2004-09-22 att det alltid var öppna och livliga diskussioner i gruppen. En stark vilja att hävda barnlitteraturens ibland ifrågasatta ställning utmärkte gruppens medlemmar. Leif Sundkvist, handläggare under åren 1985-1998, sammanfattade sina minnesbilder med att tala om "den goda stämning" som alltid rådde i grupperna. Handläggarens uppgift blev att se till att kriterierna för mångfald och bredd uppfylldes. Vidare var hans ansvar att lägga fram det långsiktiga budgetperspektivet och bevaka att kvalitetskriterierna tillämpades på ett konsekvent sätt (intervju 2004-10-05). Tua Stenström, handläggare fr.o.m. 1999, karakteriserar de grupper hon arbetat tillsammans med som "engagerade och personliga". Diskussionerna inom gruppen har varit prestigelösa och medlemmarna har alltid visat generositet $\mathrm{i}$ samtalen (intervju 2004-10-05). Bilden av arbetsklimatet i grupperna är alltså entydig.

\section{Kriterier för beslut om stöd}

Vilka kriterier har tillämpats vid beslut om stöd till barn- och ungdomslitteratur? I avsaknad av motiveringar i beslutsprotokollen får tidnings- och tidskriftsartiklar samt in- 
tervjuer ge svaren. Den första redovisningen gjordes 1980. Bibliotekarien och ledamoten i den första gruppen Britt Isaksson redogör under rubriken "Goda barnböcker och dåliga" för gruppens arbetssätt i en skrift Barnens böcker - allas angelägenhet! som utkom efter ett par konferensdagar, anordnade av kulturrådet våren 1980. Britt Isaksson konstaterar att det som präglat gruppens arbete under de första sex åren var ambitionen att ge stöd till böcker som "visar sammanhangen", "formulerar problem och ger antydan till lösningar", skildrar" nya miljöer och nya yrkesroller" samt belyser frågor om liv och död. I samma skrift formulerar ledamoten och författaren Harry Kullman sin önskan om "böcker som brinner". Han konstaterar att de problemorienterade böckerna fått en stor dominans i utbudet av barn- och ungdomslitteratur. Detta har kanske fått konsekvensen att vissa "inne-ämnen" ej alltid behandlats på ett konstnärligt genomfört sätt. Under sin tid i arbetsgruppen hade han iakttagit att i många böcker fanns "brister både $\mathrm{i}$ innehållet (idéns utförande, karaktärisering) som i det tekniska utförandet (disposition, synvinkel, tempo)". Kerstin Stjärne ger i samma skrift under rubriken "Det hotade språket" sin syn på betydelsen av ett litteraturstöd. Om nya böcker skall komma fram i samband med litteraturstödet, måste det ske i samspel med en kvalificerad diskussion om litterär och konstnärlig kvalitet.

\section{Kampen mot den kommersiella koden}

Den första arbetsgruppens ordförande åren 1975-1977, bibliotekarien Eva Viirman, hävdade i min intervju med henne att "kampen mot den kommersiella koden" var den viktigaste motiveringen för arbetet i gruppen. Barnens - ej förlagens - behov var viktigast att motsvara (telefonintervju 1995-02-28). Hen- nes efterträdare som ordförande under åren 1977-1982, läkaren Lars Weinehall, ville i samtal med mig framhålla att författarens förmåga att förmedla en upplevelse och skapa liv i en text var det viktigaste för att ge stöd till en bok (intervju 1995-04-05). Han såg som sin uppgift att förmedla ett läsarperspektiv vid besluten. För ordföranden åren 1987-1991, läraren och SÖ-konsulenten Per Settergren, var gestaltning och komposition det avgörande. Gruppens sammansättning kunde leda till diskussioner om den "smala" litteraturen skulle värdesättas före den som barnen/eleverna i verkligheten läste. Han upplevde ej att gruppen var särskilt känslig för trender i utgivningen. Stort inflytande i gruppen hade enligt Settergren ledamöterna med litteraturvetenskaplig bakgrund (intervju 1995-03-21).

Leif Sundkvist, handläggare under åren 1985-1998, påpekar att den ovannämnda "kommersiella koden" under de första åren senare ersattes av en vidare litteratursyn, som också poängterade genremässig bredd och beaktande av olika bristområden (intervju 2004-10-05 ). Jan Nilsson, ledamot under de första åren (se ovan) konstaterade i ovannämnda artikel ("Stöd eller inte stöd ?" Arbetet 10.7.1987) att ett problem vid bedömningen var den "gråzon" som utgörs av de böcker som ur en kvalitetsaspekt kan kallas mellanböcker. Inte bara litterära och språkliga aspekter bör beaktas. Även bruksböckerna bör uppmärksammas med stöd, då de fyller en viktig funktion i skolan. För ordföranden under åren 2001-2004, bibliotekschefen Staffan Wennerlund, är det viktigt att gruppen "plockar pärlorna ur bokfloden". Det finns hos gruppen ett kulturpolitiskt ansvar, som ibland kan medföra att den s.k. ribban vid besluten får sänkas något för att en bok med ett viktigt budskap skall kunna ges stöd (telefonintervju 2004-09-29). 


\section{Kvalitetsbegreppet}

Det är påfallande att under ett stort antal år erfarenhetsöverföringen mellan de olika grupperna skedde via kulturrådets handläggare, ej genom direkta kontakter mellan avgående och tillträdande ordförande. Detta har framgått vid mina intervjuer med de första årens ordförande. Av ovan citerade uttalanden framgår hur i efterhand de olika ledamöterna vill karakterisera sina bedömningsgrunder. I huvudsak har innehållsoch språkaspekter varit i centrum, även om nyttoaspekten, t.ex. skolans behov, ibland har fått styra besluten. Förordningens ord om "mångsidighet och kvalitet" kan sägas vara övergripande och innefatta de karaktäriserande ord som använts av beslutsfattarna. Att ordet kvalitet givetvis inte är entydigt framgår t.ex. när en av arbetsgruppernas ledamöter, författaren Anna-Clara Tidholm, i en artikel med rubriken "Låt barnböcker tåla konkurrens" skriver:" Det statliga litteraturstödet för utgivning av barn- och ungdomsböcker håller barnlitteraturen under armarna. Även här tänjs kvalitetsbegreppet ordentligt. / ... / De sämsta får naturligtvis inte stöd men att hålla fast vid kvalitetskrav när kvalitet ofta saknas är en svår uppgift" (Göteborgs-Posten 17.2.1999).

\section{Nyckelord och värderingsgrunder}

Behovet att i skrift sammanställa de värderingsgrunder som tillämpats under senare år ledde fram till att arbetsgruppen för barnoch ungdomslitteratur hösten 2001 utformade en sammanställning med rubriken Kvalitetskriterier för barn- och ungdomslitteratur. Nyckelorden i denna sammanställning återfinns i det generellt utformade avslagsbrev, som citerats ovan vid redogörelsen för stödgruppernas arbetssätt, samt i den allmänna information om litteraturstödet som utkom i sin senaste version 2004.
De ovannämnda nyckelorden är intensitet, komplexitet och originalitet. Detta tolkas som frågor om hur berättelsen är gestaltad, trovärdighet i berättandet, att berättelsen förmår engagera läsaren och att den har en egen ton och inte är förutsägbar. Språket skall vara funktionellt, språkligt riktigt samt rikt och levande. Det skall vara anpassat för den tänkta målgruppen. Berättelsens idé skall hålla och innehållet skall gestaltas, inte beskrivas. Här konstateras också att innehållet inte får stå i strid med FN:s deklaration om mänskliga rättigheterer eller FNs barnkonvention. Intressant är noteringen om anledningar till avslag. Här nämns bl.a. fördomsfulla personteckningar, enkla lösningar på svåra problem och att innehållet lämnar läsaren likgiltig. Värt att notera är även att positiv särbehandling kan tilllämpas även om alla ovannämnda kriterier inte uppfyllts, nämligen om boken är skriven av en debutant, om det gäller översättningar från udda språkområden och om det gäller nyskapande produktioner.

Till skillnad från de första tjugofem åren finns alltså 2004 anvisningar för bedömning av ansökningar om litteraturstöd. I det ovannämnda protokollet från ordförandemötet har även förslagits att vissa nyckelord skall kunna fogas till gruppens arbetslistor. Har detta haft någon effekt på gruppens arbete? Kan - för att hänvisa till ett citat ovan det uppfattas som censur att vissa nyckelord anges i ett offentligt dokument om hanteringen av litteraturstöd? Medlemmarna i den stödgrupp som arbetar 2004 har på min förfrågan intygat att kriterierna inte känts som en hämsko utan som ett stöd vid bedömningen av böckerna. En viktig fråga vid samtalen har varit: Var skall vi lägga ribban? Under ytan kan diskussionerna om denna ribba ha påverkats av kännedomen om nyckelorden. Vid det sammanträde med ar- 
betsgruppen som jag var närvarande vid den 6 september 2004 kretsade mycket av samtalet kring frågorna om i vilken mån boken hade en hållbar idé och om texten var engagerande ur ett läsarperspektiv. Samma utgångspunkter för stödbesluten har varit dominerande under åren 2002-2004, vilket framgår av de samtal som jag haft med handläggaren under denna period.

\section{Stödets effekter}

Vilka effekter har stödet haft? Svaret kan fås, dels genom de årsredovisningar som avgivits av kulturrådet, dels genom de statliga utredningar som publicerats under den aktuella perioden. I detta sammanhang är det också viktigt att få reaktioner från den part som direkt berörs av stödet, nämligen förlagen.

Redan två år efter litteraturstödets införande kom den första utredningen med en utvärdering av litteraturstödet. Det var betänkandet Statligt litteraturstöd (Ds U 1977:14), där utredaren stadsbibliotekarien Bengt Holmström konstaterar att stöd till litteraturen är "en angelägenhet av grundläggande betydelse för en fungerande demokrati" (s. 9). Han föreslår förenklingar i beslutsordningen, som dittills inneburit att skiftande regler tillämpats inom de olika stödordningarna. För att åstadkomma detta föreslår han att en enda arbetsgrupp skall bedöma ansökningar från alla kategorier utom facklitteraturen. Företrädare för barn- och ungdomslitteraturen hade framfört att denna genre bör bedömas på samma premisser som vuxenlitteraturen. En viss automatisering av stödbesluten skall också prövas. Dessa förslag ledde emellertid ej till resultat i den kommande propositionen. Beträffande barn- och ungdomslitteraturen konstaterar Holmström att antalet ansökningar till stödköp minskade under budgetåret 1976/77, vilket kan ha berott på att "förläggarna dragit lärdom av ar- betsgruppens bedömningar" (s. 51). Utredaren påpekar vidare risken med att den ovannämnda nya arbetsgruppen skulle kunna betraktas om en censurmyndighet. Förlagen kan tänkas anpassa sin utgivning efter de dominerande värderingarna inom arbetsgruppen. Detta skulle innebära en "helt oacceptabel maktkoncentration", vilken måste mötas med åtgärder för att sprida beslutsfattandet och motverka statliga censurtendenser (s. 70).

\section{Bokbranschutredningar}

1980 års bokbranschutredning ansåg i sitt betänkande Stöd till bokutgioning och bokförlag - en utvärdering (Ds U 1981:5) att utgivningsstödet i stort sett motsvarat förväntningarna. För barn- och ungdomslitteraturens del konstateras att andelen svenska verk ökat under de senaste åren, vilket kan förklaras dels med litteraturstödets verkan, dels med en ökande medvetenhet om barnbokens betydelse (s. 45). Denna slutsats refereras också i Läs!, rapport från 1982 års bokutredning. I samma utrednings slutbetänkande Läs mera! (SOU 1984:30) påpekas att medelstillgången gällande anslaget till barn- och ungdomslitteratur visat sig tillräcklig. En mer "utvecklingsoptimistisk riktning" kan väntas på den kvalificerade barn- och ungdomsboksmarknaden (s. 59). Generellt påpekas att stödet i positiv riktning påverkar såväl bokutgivningens bredd som kvalitet. Frågorna om upplagebegränsningar och högsta tillåtna förlagsnettopriser berörs också.

\section{Några röster om litteraturstödet}

I en intervju i Svensk Bokhandel under rubriken "Bakom kulisserna på Statens Kulturråd" säger handläggaren Torbjörn Thörngren: "Skulle vi ta bort litteraturstödet i dag skulle en tredjedel av förlagen och den viktigaste utgivningen falla bort." (Svensk Bok- 


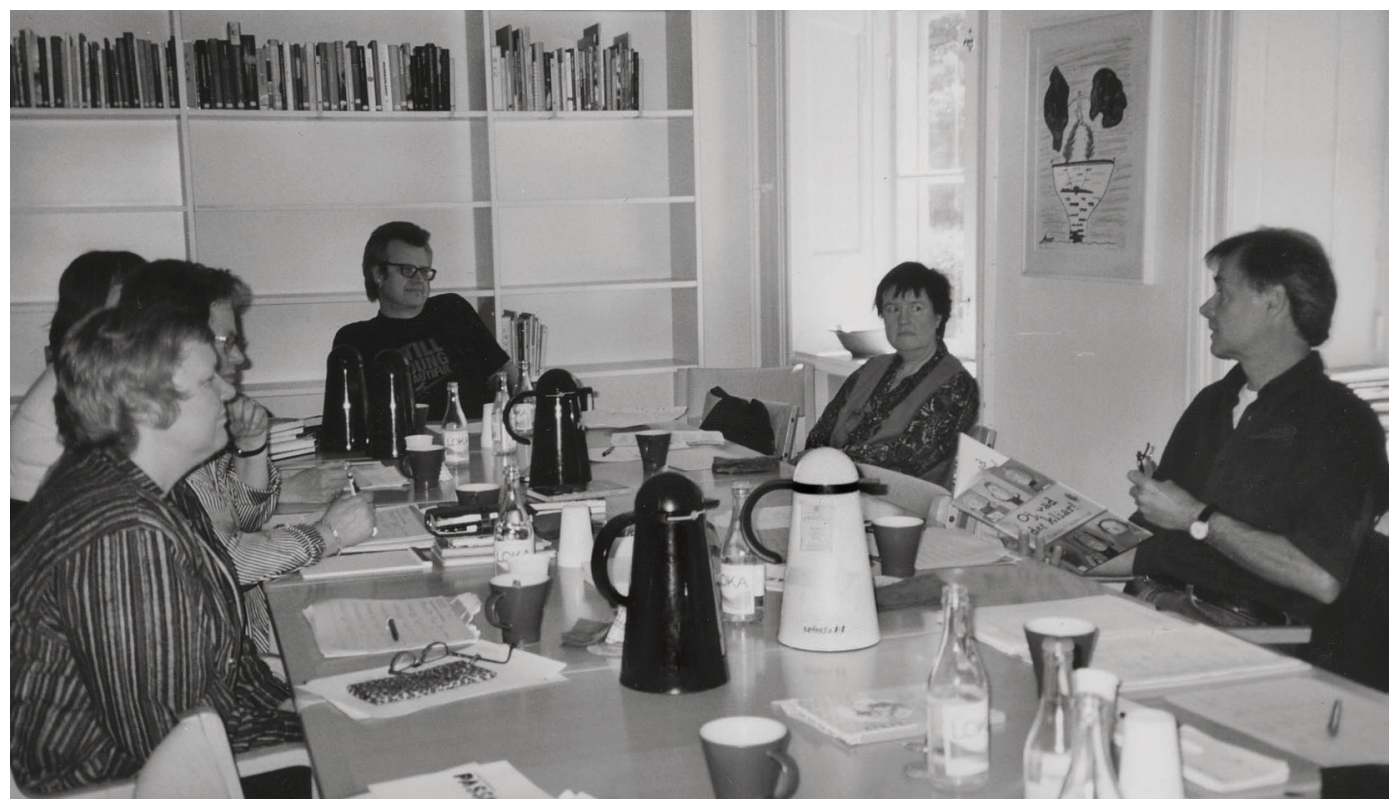

Stefan Casta lägger ut texten vid ett möte i arbetsgruppen. Övriga från vänster Kristiina Kolehmainen, Birgitta Ahlén, Ann-Christine Magnusson, Staffan Wennerlund och Anna Bengtsson. 2001.

handel 1988:2). I samma artikel påpekar han att före stödets införande hade alla småförlag försvunnit och många författare saknade utgivare. Sedan stödet tillkom har en rad mindre och mellanstora förlag bildats. I samma tidskriftsnummer finns ett reportage från ett sammanträde med arbetsgruppen för svensk skönlitteratur. Rubriken är något provokativ: "Statens litterära smak". Här hävdas också att det är samma personer som skriver tidningarnas recensioner och som fördelar stödet.

Några år senare kommenterar litteraturvetaren och kritikern Magnus Eriksson litteraturstödet under rubriken "Mankell men inte Lindegren" (Smedjan 1995:1). Han är synnerligen kritisk till stödets effekter. Det "stimulerar inte till högkvalitativa, populära eller ambitiösa böcker eller litterära projekt". Ett problem han tar fram är att stöd ges åt kommersiellt framgångsrika förlag. Det borde egentligen ges till böcker som inte skulle ha givits ut annars och som uppfattas som värdefulla. Eriksson anser att det har skapats" ett slutet system av författare, förläggare och professionella läsare". Hans exemplifiering kommer inte från barn- och ungdomslitteraturens område men tål ändå att refereras i ett sammanhang som gäller barn- och ungdomsböcker.

Docenten i litteraturvetenskap Rolf Yrlid fortsätter Magnus Erikssons kritik i sin debattartikel "Varför fungerar inte bokbranschen?" (Kulturrådet 1995:6). Yrlid hävdar att den svenska bokmarknaden fungerar dåligt och ställer frågan om den skulle fungera bättre om litteraturstödet revs upp: "Är det de statliga stödåtgärderna som underminerat branschen och minskat förutsättningarna för skapande av en ny och levande litteratur?" Hans svar blir att det är avskaffandet av de fasta bokpriserna som lett fram till den aktuella situationen. Det beror inte på litteraturstödet att bokmarknaden inte uppfyller 
kraven på ett vitt förgrenat distributionssystem och att bokpriserna försvårar möjligheten att göra böckerna åtkomliga för alla intresserade läsare.

\section{Kulturrådets syn på litteraturstödet}

Kulturrådets egen syn på stödets effekter redovisas bl.a. i två rapporter, Boken - en översikt II (Rapport från statens kulturråd 1988:4) och Boken - en översikt III (Rapport från statens kulturråd 1989:2). Där finns detaljerade redogörelser för stödets utveckling. Exempel på detta är att under 1980-talets senare år fick barn- och ungdomslitteraturen det genomsnittligt lägsta stödet per titel, ca 20000 kronor. Stödandelen för samma kategori har minskat. (Boken III, s. 27). Förslag läggs också att öka stödets omfattning till samtliga litteraturkategorier.

Kulturutredningen hävdade i sitt slutbetänkande Kulturpolitikens inriktning (SOU 1995:84) att de små kvalitetsförlagen etablerades bl.a. med hjälp av litteraturstödet. I detta betänkande refereras också de olika uppfattningar som funnits om effekten av att villkoret för stöd var att förlaget tillämpade de maximipriser som staten fastställt. Utredningen fastslog också att de statliga stödinsatser som funnits ej föranledde någon ändring gällande utformningen av stödet. Att stödets omfattning i viss mån kan sägas vara marginell framgår av att det årligen omfattar endast ca $2 \%$ av den totala marknaden för allmänlitteratur (Per I. Gedin, Litteraturen i verkligheten, s. 243).

\section{Ambitiös utgivning}

Litteraturstödets betydelse för förlagens utgivning har dokumenterats i flera sammanhang. Kulturrådet har i sina anslagsframställningar vid flera tillfällen resonerat kring stödets effekter. I Statens Kulturråds fördjupade anslagsframställning 1997-1999 kon- stateras att stödet utan "otillbörlig styrning" skall öka möjligheterna för förlagen att bedriva en ambitiös utgivning (s. 255). Det skall fungera som ett stimulans- men ej branschstöd. En effekt har blivit att utgivningen på små och mellanstora förlag har ökat. Inom barnlitteraturen dominerar inte de stora förlagen på samma sätt som när det gäller skönlitteratur för vuxna. Här kan noteras, att $i$ anslagsframställningen påpekas att arbetsgrupperna inte får ta egna initiativ för att täppa igen luckor i utgivningen (s. 258). I framställningen nämns också att kritik funnits att stödet skulle ha en allför starkt stimulerande effekt. Stödet skulle ha stimulerat små förlag att ge ut mediokra böcker. Av framställningen framgår inte om denna kritik gäller barn- och ungdomslitteraturen. Däremot framhålls att en minskning av stödet till denna litteraturkategori skulle kunna innebära att utgivningen blir mer massmarknadsinriktad. De mindre förlagens insatser skulle riskera att gå helt förlorade (s. 269).

I bokutredningens slutbetänkande Boken i tiden (SOU 1997:141) understryks att stödet haft stor betydelse för de mindre och medelstora förlagen. Utgivningsstödet har bidragit till att förlagen tagit risken att ge ut även smala titlar (s. 159). Kritik har förekommit mot att det är titlar från de större förlagen som får den största tilldelningen. Att här göra en begränsning vid urvalet av böcker som tilldelas stöd skulle dock få en styrningseffekt som kan påverka kvalitetsmålet för utgivningen.

En annan infallsvinkel har Hans Johansson och Curt Paulsson, som i sin utredning Statens kulturråds litteraturstöd (Grafiska institutet IHR Research paper 2000-1) ser på utveckling och framtida utformning av stödet. Enligt deras uppfattning bör nuvarande upplagegränser för stöd anpassas till de nya 
alternativa medierna, t.ex. elektroniska böcker. För barn- och ungdomslitteraturen konstaterar de att denna litteraturgenre från slutet av 1980-talet haft en snabbare ökning av högsta tillåtna f-pris än svensk skönlitteratur.

\section{Bredd och mångsidighet}

Inför kulturrådets omvärldsanalys våren 2002 utformade förlagschefen Kerstin Aronsson på rådets uppdrag en rapport om det statliga litteraturstödet Det statliga litteraturstödet - underlag till en omvärldsanalys mars 2002. Hon har intervjuat ett trettiotal berörda parter, av vilka hälften var förläggare och de övriga representanter för branschorganisationer samt kulturrådets arbetsgrupper. Tre viktiga frågor som ställdes var:

\section{Uppfylls målet med bredd och mångsi-} dighet i bokutgivningen?

2. Vilka effekter har upplagespärren för titlar om minst 6000 exemplar haft?

3. Finns det andra tänkbara styrinstrument för ett litteraturstöd med bibehållet kvalitetsmål?

I sin analys konstaterar Aronsson att beträffande barn- och ungdomslitteraturen har under perioden 1979-2000 antalet ansökningar stigit markant liksom beviljandegraden. Antalet utgivare har sjunkit något och de mellanstora barnboksförlagen har blivit färre. De flesta intervjuade är övertygade om att stödet bidragit till att bredd och mångsidighet bevarats inom bokutgivningen. Några anser att stöd kan bli kontraproduktiva genom att det växer fram informella regler kring vem som får stöd och varför. Att varje titel bedöms på en kvalitetsgrund har enligt de flesta intervjuade givit stödet en stark legitimitet. En intressant iakttagelse görs när det gäller stödets effekt att bygga upp författarskap. Om stödet inte fanns skulle tålamodet vara kortare med författare som inte bär sig. Här konstaterar utredaren att detta skulle vara tydligast inom barn- och ungdomslitteraturen. Totalt har bredden och mångsidigheten gynnats av stödets förekomst. Inga slutsatser kan dras av hur upplagespärren påverkat utgivningen. En förändring som kan diskuteras är om prispressen kan konstrueras på annat sätt än det som hittills gällt.

I kulturrådets Årsredvisning 2003 framhålls att konstruktionen med litteraturstödet "inte kan styra utgivningen annat än i ett långt perspektiv. Det är därför viktigt att betona att syftet med litteraturstödet är att främja både kvalitet och mångsidighet i bokutgivningen"(s.17f). Kulturrådet konstaterar i detta sammanhang att framför allt de mindre förlagen är beroende av stödet för att kunna ha en högkvalitativ utgivning. Antalet ansökningar har ökat, böckerna har blivit dyrare och därmed har stödbeloppen fått större omfattning. Risken finns att det etablerade gagnas, medan det udda och nya, t.ex. lättlästa böcker som riktar sig till barn, inte kan få stöd.

\section{Barnboksförlagens reaktioner}

Några reaktioner från enskilda barnboksförläggare kan också vara av vikt att anföra. Carl Hafström, förlagschef under olika perioder på såväl ett stort förlag, Bonniers Juniorförlag som ett mindre, Berghs förlag, hävdar att stödet haft mycket stor betydelse framför allt för de mindre förlagen. Utan stödet skulle ungdomsboksutgivningen ha äventyrats under 1980-talet. För ett större förlag var det viktigt att söka på det mesta av utgivningen för att pröva kulturrådets krav. Hafström medger att ett visst inflytande fick utgivningsbesluten även på utformningen av det kom- 
mande årets böcker. Stödet hade givetvis mindre ekonomisk betydelse för det större förlaget, medan det för det mindre kunde sägas utgöra förlagets vinst för budgetåret (intervju 1995-10-05).

Kerstin Aronsson, förlagschef vid Kabusa Förlag, som citerats ovan i avsnittet" Motivering av avslag" samt i samband med referatet av hennes utredning, gör en iakttagelse som visar vad som kan ha haft betydelse för utgivningens utformning: "Toleransen är mindre vid bedömning av barn- och ungdomslitteratur än av vuxenlitteratur när det gäller bokens språk och syfte" (telefonintervju 2004-09-30). En sådan slutsats kan med hänvisning till Hafströms uttalande ovan - påverka besluten för kommande års utgivning.

Rod Bengtsson, förläggare vid Bonnier Carlsen bokförlag, hävdar att för bokförlagen innebär stödet en ekonomisk trygghet. Det är rimligt att ansökningarna från såväl större som mindre förlag bedöms med samma kvalitetskriterier och ej med hänsyn till förlagens storlek. För barn- och ungdomslitteraturen är det synnerligen viktigt att stödbeloppen ökar. "Det är ett övergripande samhällsansvar att tillgodose barn och ungdomar med en riklig utgivning av böcker för att stimulera läsintresset. Litteraturstöd, satsningar på skolbiblioteken och olika vägar att öka läsintresset är medel för att förverkliga detta ansvar (telefonintervju 200410-13).

Marianne Eriksson, förläggare vid Eriksson \& Lindgren bokförlag, ser litteraturstödet som en naturlig del i budgeten. Ett beviljat stöd kan också ge ett lägre bokpris (telefonintervju 2004-10-15). David Stansvik, förlagschef för bokförlaget Nya Doxa, anser att stödet haft en positiv effekt och ökat mångfalden inom utgivningen. Detta har varit till fördel för läsarna. Mindre förlag har kunnat utge litteratur som varit kommersiellt gångbar. Översättningslitteraturen har gynnats. Även om alla ansökningar ej beviljats har stödets stimulanseffekt varit generell. Nuvarande stödordningar har en tillräckligt vid inriktning för att kulturrådets arbetsgrupper skall kunna låta "åsiktvindarna" få spelrum vid bedömningen av litteraturen. "Statens ansvar är att gripa in, där marknadskrafterna ej räcker till" (telefonintervju 2004-10-13).

I tillgängliga utredningar och anslagsframställningar kan inte på ett tillfredsställande sätt fastställas den exakta effekten av litteraturstödet. I detta sammanhang bör dock nämnas att under 2000-talets början varje år utkom omkring 1000 nya originaltitlar (svenska och översättningar) inom området barn- och ungdomslitteratur, jämfört med de ca 200 titlar som beviljades stöd. Av det som anförts ovan i min framställning framgår att stödet haft en mycket stor betydelse för framför allt de mindre förlagen. Utgivningens bredd - med förordningens ord mångsidighet - har gynnats påtagligt. Det statliga stödet till barn- och ungdomslitteratur har dock ej ökat i den takt som vore önskvärd för att helt uppfylla kravet på mångsidighet i utbudet av böcker för barn och ungdom. Detta krav kan utläsas i de utredningar som nämnts ovan i beskrivningen av stödets utveckling. De ekonomiska ramarna har sannolikt ibland utgjort ett hinder för att ytterligare vidga utgivningen till nya områden. För barn- och ungdomslitteraturens utbredning till den tänkta målgruppen har även andra åtgärder varit av största betydelse, exempelvis sänkningen av bokmomsen och stödet till distribution av böcker till bibliotek. Detta ligger dock utanför ramen för denna framställning. 


\section{Litteraturstöd till barn- och}

\section{ungdomslitteratur i framtiden -} förändringstendenser

Det statliga stödet till utgivning av litteratur tillkom för att garantera en bred utgivning av litteratur av god kvalitet. Av den totala bokutgivningen vid 2000-talets början svarade barn- och ungdomslitteraturen för omkring $10 \%$. På försäljningsmarknaden utgjorde denna kategori knappt $20 \%$ av den totala volymen. Stödets betydelse har dokumenterats ovan i min framställning, dels genom hänvisning till olika utredningar och rapporter, dels genom intervjuer med olika förlagsföreträdare. Vilken utveckling kan litteraturstödet genomgå under de närmaste åren och vilka förändringar är tänkbara för att tillgodose barns och ungdomars möjligheter att få tillgång till utvecklande läsupplevelser? Vilket utrymme inom den totala statliga budgeten kommer litteraturstödet att få?

Ett perspektiv värt att nämna är att kulturens andel av den totala statsbudgeten år 2002 var endast 1,2 \% (Statens Kulturråd, Kulturstatistik 2004). Inom denna del skall bl.a. stödet till barn- och ungdomsböcker rymmas. I kulturdepartementets Dagordning för kultur 2003-2006 (Regeringskansliet 2003) påpekas att barnkulturen har en central roll i svensk kulturpolitik. Med hänvisning till FN:s barnkonvention hävdas att det sedan 1970-talet råder bred politisk enighet om satsningarna på barn och unga. I dagordningen står detta att läsa under rubriken "Barnen först". Ett steg för att förverkliga de mål som anges i dagordningen togs i september 2004, då regeringen tillsatte en aktionsgrupp för barnkultur. Denna grupp skall enligt direktiven "lämna förslag på hur barnkulturens ställning kan stärkas" (Kulturdepartementet Dir. 2004:117). I texten nämns inte stöd till litteraturutgivning, men konsekvensen av det synsätt som präglar direktiven bör vara att litteraturstöd i olika former, utgivningsstöd, distributionsstöd och stöd till läsfrämjande åtgärder prioriteras även under kommande år. Handläggningen av ansökningarna kan förenklas och med genomförande av ökad offentlighet vid avslagsbeslut kommer rättssäkerheten att öka. Det centrala är dock stödets omfattning mätt i de belopp som tilldelas kulturrådet för detta ändamål.

I avsnittet "Ideologiska bedömningar" citerades Bertil Zachrissons ord: "Litteratur är en hörnsten i samhällets kulturella ansvar". En viktig del av denna hörnsten är böcker för barn och ungdom. Med hänvisning till de ovan nämn-da direktiven om förstärkning av barnkulturens ställning blir en tänkbar tendens att litteraturstödet utvidgas och därmed barn- och ungdomslitteraturens framtida utveckling säkerställs.

\section{Ledamöter i kulturrådets arbetsgrupper för litteraturstöd till barn- och ungdomslitteratur}

1975-1977 Eva Viirman, ordf., Hasse Hansson, Britt Isaksson, Harry Kullman, Eva Melin, K G Nordström, Kerstin Stjärne

1977-1978 Lars Weinehall, ordf., Hasse Hansson, Britt Isaksson, Harry Kullman, Eva Melin, K G Nordström, Kerstin Stjärne
1978-1979 Lars Weinehall, ordf., Hasse Hansson, Britt Isaksson, Harry Kullman, Eva Melin, Kerstin Stjärne

1980-1982 Lars Weinehall, ordf., Max Lundgren, Jan Nilsson, Gunilla Noreen, Ying ToijerNilsson, Margareta Toss 
1983-1985 May Engvall, ordf., Max Lundgren, Jan Nilsson, Gunilla Noreen, Ying ToijerNilsson, Margareta Toss

1985-1987 May Engvall, ordf., Jan Nilsson, Ingegerd Martinell, Ulla Rhedin, Stefan Mählqvist, Inga Borg

1987-1988 Per Settergren, ordf., Ingegerd Martinell, Ulla Rhedin, Stefan Mählqvist, Inga Borg, Conny Zetterlund

1988-1989 Per Settergren, ordf., Inga Borg, Lena Kåreland, Ingegerd Martinell, Ulla Rhedin, Conny Zetterlund

1989-1991 Per Settergren, ordf., Susanna Ekström, Lena Kåreland, Ingegerd Martinell, Cecilia Torudd, Conny Zetterlund

1991-1993 Conny Zetterlund, ordf., Susanna Ekström, Lena Kåreland, Cecilia Torudd, Ulf Fanger, Ulla Forsén

1993-1994 Ulla Forsén, ordf., Larry Lempert, Susanna Ekström, Lena Kåreland, Cecilia Torudd, Ulf Fanger

1994 Ulla Forsén, ordf., Susanna Ekström, Ulf Fanger, Jan Hansson, Larry Lempert, AnnaClara Tidholm

1995-1997 Ulla Forsén, ordf., Jan Hansson, Britt Jakobsson, Larry Lempert, Christina Svensson, Anna-Klara Tidholm

\section{Referenser}

Gedin, Per I.: Litteraturen i verkligheten, Rabén Prisma, 2. uppl. 1997

Lennartsson, Claes: Stödordningarna för litteratur $i$ Norge och Sverige. En ideologianalytisk ansats, Småtryck från publiceringsföreningen VALFRID nr 22, 1999 (Bibliotekshögskolan i Borås).

Statens kulturråd, Boken - en översikt II (1988:4) och Boken - en översikt III (1989:2)

Statens kulturråd, Kulturen i siffror. Böcker och kulturtidskrifter 2001. (Rapport 2002:5)

Statens kulturråd, Kulturstatistik 2004 (arbetsmaterial)

Statens kulturråd, Årsredovisning 2003
1998 Jan Hansson, ordf., Mats Berggren, Britt Jakobsson, Larry Lempert, Christina Svensson, Anna-Klara Tidholm

1999 Jan Hansson, ordf., Anna Bengtsson, Mats Berggren, Britt Jakobsson, Lena KjersénEdman, Christina Svensson, Staffan Wennerlund

2000 Jan Hansson, ordf., Birgitta Ahlén, Anna Bengtsson, Mats Berggren, Lena KjersénEdman, Ann-Christin Magnusson, Staffan Wennerlund

2001 Staffan Wennerlund, ordf., Birgitta Ahlén, Anna Bengtsson, Mats Berggren, Lena Kjersén Edman, Kristiina Kolehmainen, AnnChristin Magnusson

2002 Staffan Wennerlund, ordf., Birgitta Ahlén, Anna Bengtsson, Stefan Casta, Lena Kjersén Edman, Kristiina Kolehmainen, AnnChristin Magnusson

2003 Staffan Wennerlund, ordf., Jens Ahlbom, Birgitta Ahlén, Stefan Casta, Ann-Christin Magnusson, Thomas Storn, Boel Sjöberg 2004 Staffan Wennerlund, ordf., Jens Ahlbom, Stefan Casta, Gunilla Hebert, Maria Rohlin, Thomas Storn, Boel Sjöberg

2005 Gunilla Hebert, ordf., Jens Ahlbom, Stefan Casta, Helena Magnusson, Maria Rohlin, Thomas Storn, Boel Sjöberg

Tjugo års kulturpolitik 1974-1994 (SOU 1995:85 med tabellbilaga)

Uthas Hornegård, Sarah: Litteraturstödda bilderböcker, Magisteruppsats, Institutionen för ABM, estetik och kulturstudier, Uppsala universitet, 2000

Wallinder, Alvar: Vem bestämmer? Svensk barnlitteraturutgioning - människor, miljöer och värderingar. Cikada, 1986. (Skrifter utgivna av Svenska barnboksinstitutet $\mathrm{nr}$ 23)

Yrlid, Rolf: Litteraturens villkor, Studentlitteratur,1994 